\title{
Polysaccharide-based vaccine construction against Typhoid fever and other Salmonellosis
}

\author{
P.G. Aparin, V.L. L'vov, N.P. Vaneeva, S.I. Yolkina.
}

\begin{abstract}
Abstrak
Polisakarida yang sangat murni dan non toksik yang diperoleh dari dinding sel atau kapsul kuman Salmonella digunakan untuk konstruksi vaksin. Prinsip konstruksi vaksin konjugasi dengan polisakarida spesifik $O(O-P S)$ S. typhimurium diteliti pada model mencit tifoid. Sebagai sistem pembawa O-PS digunakan karier polimer antigen sintetik: polioksidonium atau kopolimer $N$-vinil pirolidon dengan asam akrilat (NA). Berbagai konjugat tersebut memberikan reaksi yang berbeda dari O-PS yang bersifat seperti hapten dalam pembentukan AFC spesifik di limpa mencit yang diimunisasi dan dalam pembentukan antibodi IgM dan IgG serum. (Titer ELISA 1:400 - 1:2200).

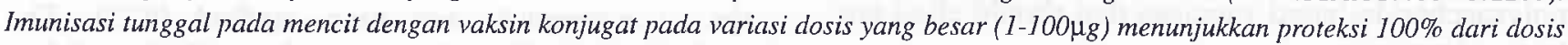
letal 20 - 100 LD5o galur virulen 4J5. Telah dibuktikan bahwa imunogenitas suatu vaksin konjugat sangat tergantung dari struktur 3 dimensi dari molekul kompleks tersebut. Konjugat yang mengandung long spacer C8 antara O-PS dan karier akan lebih meningkatkan tingkat proteksi. Vaksin konjugasi polisakarida ini dicoba pula pada salmonellosis anak babi menyusui yang diinfeksi dengan S.choleraesuis. Anak babi yang disuntik dengan vaksin konjugasi O-PS dengan NA karier diinfeksi dengan dosis letal galur virulen 380 satu bulan kemudian. 67-100\% binatang yang telah diimunisasi dapat tetap hidup, sedangkan hanya 25\% saja yang hidup bila divaksinasi dengan vaksin yang berisi kuman mati. Pendekatan pembuatan vaksin tifoid dengan mengisolasi fraksi-fraksi polisakarida yang paling imunogenik dilakukan atas dasar adanya daya proteksi yang besar dari antigen Vi. Metode tersebut dimodifikasi dengan teknik kromatografi agar vaksin ada dalam kondisi yang sangat murni. Antigen-Vi hasil kromatografi terbukti berhasil lulus dalam uji coba preklinik dan klinik dan sekarang digunakan sebagai imunisasi massal sebagai bahan aktif vaksin VIANVAC ${ }^{\circledR}$. Pendekatan lain untuk mengembangkan vaksin tifoid polisakarida adalah dengan penggunaan LPS dari S. typhi yang bersifat rendah pirogen dan rendah toksin sebagai antigen spesifik-O sekunder serta komponen ajuvan. Ambang pirogenitas dari LPS antigen tersebut adalah 0,025 $\mathrm{g} g$ per $\mathrm{kg}$ berat badan kelinci. Berbagai pendekatan yang menghasilkan pembuatan vaksin polisakarida untuk demam tifoid, tifoid mencit dan salmonellosis anak babi memungkinkan tercapainya perlindungan meskipun hanya diberikan satu kali imunisasi saja.
\end{abstract}

\begin{abstract}
Highly-purified non-toxic polysaccharides from cell wall or capsule of Salmonella are used for vaccine construction. Principles of construction of conjugated vaccine with built-in O-specific polysaccharide(O-PS) S. typhimurium were studied on mouse typhoid model. Synthetic polymer antigen carriers: polyoxydonium or copolymer of $N$-vinylpyrrolidone and acrylic acid (NA) were used as delivery systems for $O$-PS. Conjugates differ from hapten-like. $O-P S$ in generating specific AFC in the spleens of immunized mice and IgG and IgM serum antibodies (ELISA titer 1:400 - 1:2200). Single immunisation by conjugate vaccine in wide dose range (1-100 $\mu$ g) provided $100 \%$ protection of mice from lethal challenge $\left(20-100 \mathrm{LD} \mathrm{D}_{50}\right)$ by virulent strain 415 . It was shown that immunogenicity of vaccine conjugate is dependent on $3 D$ structure of complex molecule. Conjugates including long spacer (C8) between $O$-PS and carrier generate increased level of protection. Conjugated polysaccharide vaccine against piglet salmonellosis caused by S.choleraesuis was examined on suckling piglets. Piglets were injected with O-specific polysaccharide conjugated with NA carrier and challenged 1 month after by lethal dose of virulent strain 380. Survival of conjugate immunized animals was 67-100\%, survival of whole-cell killed vaccine immunized animals was $25 \%$. Isolation of polysaccharide most immunogenic fraction is an approach used for typhoid vaccine construction based on major protective Vi-antigen. This general method was modified by development chromatographical technology for vaccine Vi-antigen purification. Chromatography grade quality Vi-antigen was successfully passed through preclinical and clinical trials and is used now for mass-immunisation as active substance of VIANVAC ${ }^{\mathbb{1}}$ vaccine. Another approach to typhoid polysaccharide vaccine construction is the development of low pyrogenicktoxic LPS S. typhi as second O-specific antigen and adjuvant compound. Pyrogenicity threshold for such LPS is $0.025 \mu \mathrm{g}$ per $\mathrm{kg}$ of rabbit body weight. Different approaches to construction polysaccharide-based vaccine against typhoid fever, mouse typhoid, piglet salmonellosis permit to archive protection even under the single immunisation.
\end{abstract}

\section{Introduction}

The Salmonella microorganisms are responsible for

Institute of Immunology, Moscow, Russia millions of infected persons world-wide, thousands of deaths annually as well as for causing economic problems. Development of modern vaccines against typhoid fever and non-typhoidal salmonellosis shall be considered as priority goal for prevention and control of these infections. 
Traditional Salmonella vaccines based-on attenuated or inactivated whole-cell bacteria are used mainly for prevention of human typhoid fever or in veterinary practice to prevent salmonellosis of young domestic animals (piglets, chickens, calves). Immunisation against human non-typhoidal Salmonella infections is not undertaken at present time due to absence of the effective vaccine and its application. Limited effectivity, multiple long immunization schedule, postvaccination side-reactions and complications are well-known disadvantages of traditional Salmonella vaccines. Among the new strategies for vaccination contemplated to overcome such shortcomings are polysaccharide-based vaccines that should elicit protective immunity.

Salmonella infections provides very suitable model for studying polysaccharide approach to vaccination for several reasons:

a. capsular or/and cell wall polysaccharides are protective antigens which plays important role in pathogenesis of Salmonella infection;

b. structure, physico-chemical properties, immunochemical specificities of polysaccharides were investigated in detail;

c. well-established animals models in mice, piglets are available, for studying immune response and challenge under different Salmonella infections;

d. Salmonella produce in vitro polysaccharide antigens with significant yields which permit largescale immunizations and field trials.

In our study we used chromatographically-purified non-toxic polysaccharides from cell wall or capsulae of bacteria. O-specific polysaccharide Salmonella typhimurium 415 was obtained by mild acid hydrolysis from the relevant $\mathrm{O}$-antigen Boivin and purified by gel-filtration on Sepharose G-50 column. O-specific polysaccharide Salmonella choleraesuis 370 was isolated by the same technique. Vi-capsular polysaccharide was obtained from Salmonella typhi Ty2 and chromatographically purified. Low-toxic \& pyrogenic lipopolysaccharide (LPS) was obtained from Salmonella typhi O901.

\section{Approaches to construction of conjugated O-poly- saccharide mouse Typhoid vaccine}

Early studies in our laboratory have shown the application of synthetic polymers and copolymers of $\mathrm{N}$ vinylpyrrolidone and acrylic acid (NA) and biodestructive polymer polyoxydonium (PO) as immunopotentiator carriers for antigens. These carriers have been used as delivery system for vaccine constructed with build-in O-specific polysaccharide Salmonella typhimurium. Chromatographically-purified O-PS prepared in pure form, free of significant amounts of LPS, protein or nucleic acids were covalently bound to NA polymer modified by side-chains with primary amino groups (mNA).

The synthesis of O-PS-carrier conjugates was performed by the use well-known methods of carbohydrate activation: introduction of aldehyde groups, capable of reacting with carbohydrate aminogroups (C$1)$, carbodiimide-mediated condensation (C-2) and the cyanobromide activation method (C-3). The method of binding, based on the acylation of hydroxyl groups by bromacetylbromide is not widely known; we used it to obtain conjugate C-4.

The conjugates C-1,C-2,C-3,C-4 were examined for their ability to induce $\mathrm{O}$-specific antibody forming cells (AFC) and serum antibodies. The number of Ospecific AFC was determined by modified method Jerne. All of the mice immunized by conjugate C-4 elicited significant 10 -fold increase of $\mathrm{O}$-specific AFC in the spleen. Injection of O-PS in dose of 100 $\mu \mathrm{g}$ led to only 1.5-2.0 fold increase the number of $\mathrm{AFC}$ in spleen. Mice immunized by conjugates C1,C-2,C-3 including similar dose of O-PS produced AFC levels differs slightly from that elicited by pure O-PS indicating that methods of conjugation was crucial for an effective humoral response. We found that O-PS correctly conjugated with polymer carrier elicited serum $\mathrm{O}$-specific IgG and $\operatorname{IgM}$ antibodies after single injection. Hapten-like pure O-PS was found non-immunogenic even under double immunisation.

Screening of conjugate samples with different composition led to reveal cyanur chloride as suitable agent for O-PS build-in. Technique of conjugation with biodestructive non-toxic carrier $\mathrm{PO}$ have been developed.

Once it was established, that O-PS - polymer conjugates are capable to induce anti-O humoral immune response, the efficiency of the various preparations to protect mice from mouse typhoid challenge was determined. To determine protective activity, O-PS or conjugates were injected to mice intraperitoneally in doses $1,5,25,125$, and $625 \mu \mathrm{g}$. 10-14 days later all animals were intraperitoneally challenged by virulent $S$. typhimurium strain in lethal dose $20 \mathrm{LD}_{50}$. The $\mathrm{LD}_{50}$ of virulent strain was specially checked for each experiment by infecting the groups of control 
animals with doses $10^{3}, 10^{4}, 10^{5}, 10^{6}, 10^{7}$ microbial cells and calculated by Korber's formula.

Experimental data, demonstrating the dynamics of mice mortality immunized with O-PS and C-4 conjugate and challenged by dose $20 \mathrm{LD}_{50}$ of virulent strains are presented in Figure 1. The death curves indicated weak protection after immunisation by pure O-PS. This preparation protected the mice only when introduced in a very high dose $-625 \mu \mathrm{g}$. Protective effect of O-PS was significantly improved by conjugation with synthetic carrier. Conjugate, in spite of O-PS content $25 \%$, induced strong postvaccination immunity in all mice immunized by doses 625,125 and $25 \mu \mathrm{g}$ and protected animals immunized with doses 5 and $1 \mu \mathrm{g}$ more effectively than O-PS. Control mice injected by challenge dose died during 5-7 days.



Figure 1. Protective effect of the conjugate after challenge with $20 L D_{50}$ of $S$. typhimurium

Index $\mathrm{ED}_{50}$ was calculated for comparing protective effect of O-PS in pure and conjugated form. Table 1 shows that the value of $\mathrm{ED}_{50}$ for O-PS build-in C-4 conjugate is significantly low than for free antigen. The conjugation of O-PS with mNA led to 20-40-fold increase of its protective efficiency.
We investigated some additional characteristics of artificial constructed O-PS immunogens and their influence on immunogenic properties. Simple variation of antigen or carrier content into conjugate had no significant effect on immunogenicity. Conjugates with variation $\mathrm{w} / \mathrm{w}$ ratio $\mathrm{O}-\mathrm{PS} / \mathrm{mNA}$ from 0.5 to 10 revealed similar immunogenicity.

Variation of another parameter of construction length of spacer (side chain ) between polysaccharide and carrier, in contrast, affect the immunogenic and protective properties of vaccine conjugate. Long spacer conjugate was obtained by elongation of side chain of NA carrier by octamethylenediamine (C-8). Conjugate induced a significant rise of $\mathrm{O}$-specific serum antibody level in mice and provided protective effect against mouse typhoid higher than conjugate with short (C-2) spacer. Index ED S0 $_{50}$ for long-spacer conjugate was greatly lower than $\mathrm{ED}_{50}$ index for antigen. Since reliable protection against mouse typhoid virulent strain could be elicited by long-spacer conjugate, we investigated whether or not conjugate induce protection against challenge with high virulent dose $100 \mathrm{LD}_{50}$. Results of this experiment demonstrated that single immunisation of mice by conjugate led to considerable protective effect under the challenge with increased dose. It was shown that long spacer conjugate high immunogenicity isn't caused by ordinary increase of adjuvanticity of modified carrier. Immunisation by mixture O-PS with $\mathrm{mNA}(\mathrm{C}-8)$ did not elicit satisfactory immune response.

Another approach to construction led into creation of immunogens which combined of three-components: O-PS, polymer carrier and protein antigen (flagellin). Developing three-component immunogens, we made two main assumptions. First, to use protective potential of additional $\mathrm{H}$ i;12 specific antigen. Second, to use flagellin as secondary protein carrier which switch-on carrier-specific mechanism of immune response eliciting. Three-component conjugate was ob-

Table 1. Protective efficiency of free and conjugated O-PS S.typhimurium.

\begin{tabular}{|c|c|c|c|c|c|c|}
\hline Experiment & Jmmunogen & $\begin{array}{c}\text { Antigen polymer } \\
\text { weight ratio }\end{array}$ & $\begin{array}{c}E D_{50} \text { conjugate } \\
\mu \mathrm{g}\end{array}$ & $\begin{array}{c}\text { ED }_{50} \text { build-in O-PS } \\
\mu \mathrm{g}\end{array}$ & $\begin{array}{c}\mathrm{ED}_{50} \text { O-Ps free } \\
\mu \mathrm{g}\end{array}$ & $\begin{array}{c}\mathrm{ED}_{50} \text { free O-PS } \\
\mathrm{ED}_{50} \text { build-in O-PS }\end{array}$ \\
\hline \multirow[t]{2}{*}{1} & C-4 & $1: 3$ & 1.232 & 0.308 & - & 17.9 \\
\hline & O-PS & - & - & - & 5.508 & - \\
\hline \multirow[t]{2}{*}{2} & C-4 & $1: 3$ & 0.867 & 0.122 & - & 45 \\
\hline & O-PS & - & - & - & 5.0 & - \\
\hline
\end{tabular}


tained on the base of biodestructive $\mathrm{PO}$ carrier with component ratio O-PS / FLA / PO carrier 1:1:5. It should be noted that PO licensed immunomodulator widely used for treatment in clinical practice. Conjugate elicited levels of $\mathrm{O}$-specific antibodies higher than those elicited by ordinary bivalent conjugates and provide reliable protection after single immunisation.

\section{Development of Salmonella choleraesuis polysac- charide vaccine}

Approaches to mouse typhoid vaccine construction with build-in O-PS formed a background for conjugated vaccine development against piglet salmonellosis. Piglet salmonellosis is caused by bacteria $S$. choleraesuis known as one of the most virulent, dangerous, but seldom infects man Salmonella serotype. Suckling piglets are mainly affected by this bacteria during the first months of life. Epizootics of piglet salmonellosis inflict serious damages to pig-breeding farms.

Chromatographically-purified O-PS S. choleraesuis with O-specifities O:6,7 have been bound with NA polymer carrier modified with long (C-6) side chain with use as conjugating agent cyanur chloride. Conjugate with build-in O-PS S. choleraesuis was investigated in experiments on suckling piglets for its ability to induce protection. 10-days old piglets were $\mathrm{i} / \mathrm{p}$ or s/c injected by conjugates in doses estimated to antigen content $1,10,100,1000 \mathrm{mg}$ per $\mathrm{kg}$ body weight. Immunisation of piglets by conjugate vaccine did not cause any toxic reactions. It was shown that parameters of growth and development, weight increases of immunized piglets were not differ from corresponding indexes of control animals. The piglets were challenged two or four weeks after immunisation by $10^{8}$ cells of virulent strain S. choleraesuis 370 and protection was evaluated.

Summarizing piglet immunisation data several conclusions can be made. $100-67 \%$ protection of piglets after challenge in natural conditions have been archived by conjugate immunisation with established design O-PS, long spacer, mNA carrier injected in doses $10,100,1000 \mathrm{mg}$ per $\mathrm{kg}$ of body weight. The dose $1 \mathrm{mg}$ was revealed as low-immunogenic. Lower levels of protection were induced by O-PS which never protected all animals in the experiment. Wholecell killed $S$. choleraesuis vaccine protected only quarter from the quantity of immunized piglets. Different immunisation schemes provided the similar level of protection.
It is possible to make conclusion concerning the duration of immunity. The piglets were kept as minimum as 1 month after immunisation. It was important for taking into account well-known fact that the first two month of piglet life are crucial period of susceptibility to salmonellosis infection. It should be noted that we have not registered significant increase of $\mathrm{O}$-specific antibody levels in the serums of piglets after immunisation. The clear correlation between immunogenic and protective properties for piglet salmonellosis vaccine wasn't found unlike mouse typhoid vaccine. Possible explanation of this fact- high preliminary level of Ospecific antibodies revealed in suckling piglets which masking vaccine-induced antibody increase. HA-titer anti-O:6,7 antibodies in suckling piglets serums under natural conditions varied from $1 / 16$ to $1 / 64$. Specific antibodies as factor of colostral immunity transferred to piglets which received mother milk.

Piglet protection data were evaluated additionally by $\mathrm{ED}_{50}$ index estimated for each experiment. $\mathrm{ED}_{50}$ for conjugated polysaccharide varied from 3.2 to 14.5 mg per kg body weight slightly varied on scheme and dose of immunisation. Index $\mathrm{ED}_{50}$ was significantly higher for non-conjugated antigen 68-149.9 mg per $\mathrm{kg}$ body weight.

\section{Typhoid fever polysaccharide vaccine construc- tion}

Major protective capsular Vi-antigen is characteristic feature of typhoid fever bacteria important for the polysaccharide vaccine construction. Exactly Vi-antigen attract main attention of typhoid polysaccharide vaccines developers. Comprehensive investigations by J.B. Robbins group led to reevaluation of Vi-antigen potential as protective immunogen and development of Vi-antigen polysaccharide typhoid vaccine ${ }^{l}$.

Isolation of polysaccharide most immunogenic fraction is an approach used for Vi-antigen typhoid vaccine construction. Original technology of chromatographical isolation of vaccine $\mathrm{Vi}$-antigen have been developed by our group for full execution of this principle. Two main requirements must be performed for obtaining vaccine Vi-antigen. Vi-antigen must be obtained in native non-denatured form without alteration of immunodominant O-acetyl groups. High molecular weight fraction of $\mathrm{Vi}$-antigen eluted under the chromatography on Sepharose CL-4B column before distribution coefficient KD 0.25 must consist no less than $50 \%$ of preparation substance. Low molecular weight depolymerized Vi-antigen can't be utilized for vaccine due to low-immunogenic properties. Unlike 
traditional technology, this technique enables us to control the molecular weight vaccine parameters during manufacturing and to get a reliable separation of high molecular weight part of Vi-antigen.

Chromatographically-purified Vi-antigen has successfully passed through preclinical and clinical trials and is used now for mass-immunisation as active of substance of VIANVAC ${ }^{\circledR}$ vaccine. It should be noted that the new formula of Vi-antigen typhoid vaccine fully meets WHO requirements for polysaccharide $\mathrm{Vi}$-antigen vaccine ${ }^{2}$. Single immunisation by the vaccine elicited significant rises not only $\operatorname{IgG}, \operatorname{IgM}$, but IgA specific antibodies too (Figure 2). IgA specific antibodies are very important instrument of forming mucosal immunity against intestinal infection. Activation of cellular immunity by vaccine Vi-antigen have been shown during vaccine experimental studies. Recently the effectivity of immunisation by VIANVAC was demonstrated under conditions of an epidemic outbreak in Tajikistan.

Developed technological approach principally shall be used for further construction of vaccine based on high molecular weight of Vi-antigen portion. Parameters of isolation shall be more raised than present WHO approved. It may be expected that $\mathrm{Vi}$-antigen which contain main substance before fixed distribution coefficient $\mathrm{KD}<0.10,0.05$ shows high immunogenicity.

Another approach to typhoid polysaccharide vaccine construction is connected with development of lowtoxic \& pyrogenic LPS $S$. typhi. LPS is well-known protective antigen in typhoid fever infection. Production O:9,12 - specific antibodies is an important factor of protection in the course of infection. New variant of LPS immunogen obtained from $S$. typhi strain O:901 showed a significantly higher safety profile than ordinary preparation. Pyrogenicity of such preparation satisfied WHO pyrogenicity requirements for polysaccharide vaccine $(0.025 \mu \mathrm{g}$ per $\mathrm{kg}$ of rabbit body weight). This preparation induced $\mathrm{O}$-specific antibody formation in mice and their protection against $S$. typhi challenge.

\section{Concluding remarks}

Our results suggest that it is possible to form protective immunity against different highly-virulent $\mathrm{Sal}$ monella infections by immunisation with rationally constructed polysaccharide vaccines. Usually single immunisation by polysaccharide vaccine is necessary to achieve reliable protection.
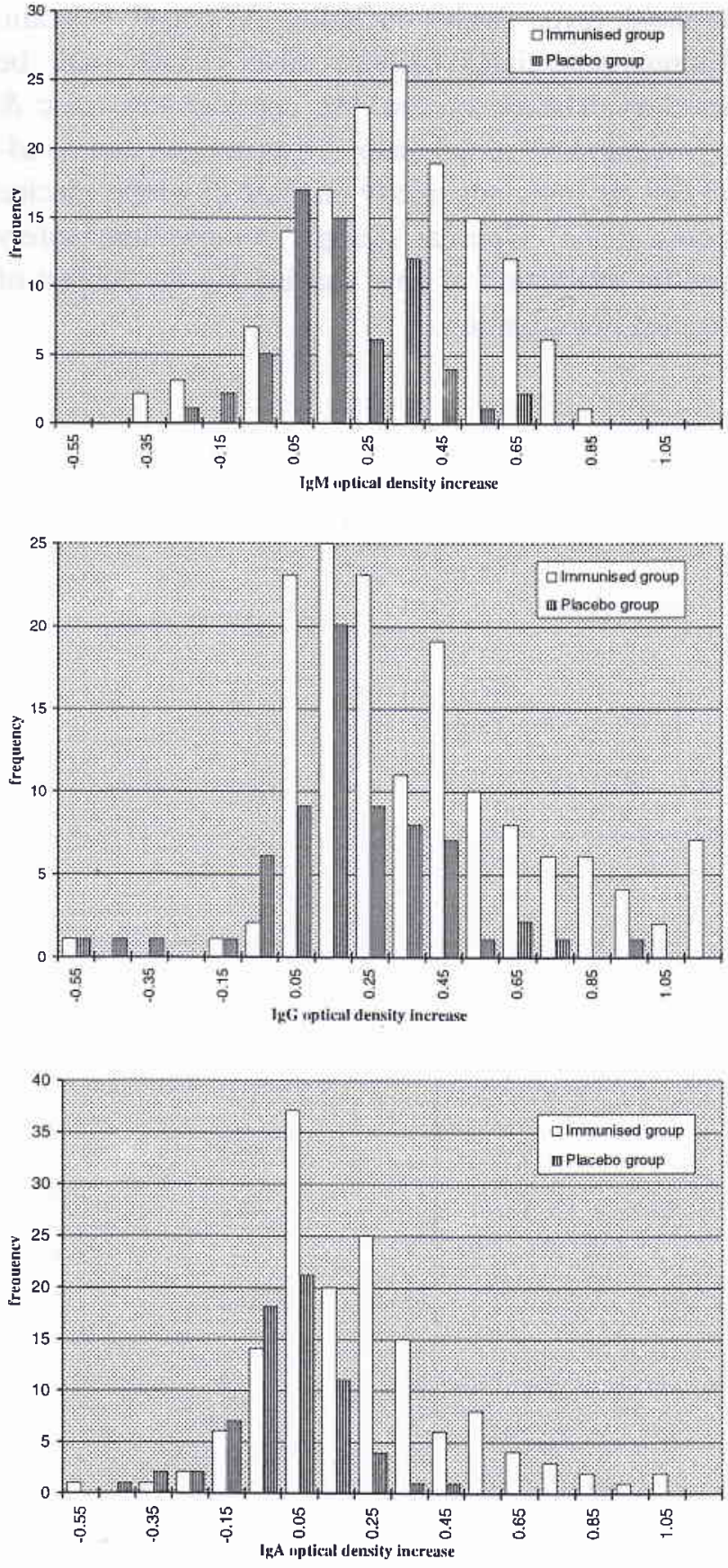

Figure 2. IgA, IgM and IgA Vi-specific antibodies after immunisation by VIANVAC ${ }^{\circledR}$ vaccine under the double-blind, randomized clinical trials.

Another result of our vaccine investigations on different Salmonella infections is development of a set of components and methods for construction of new generation polysaccharide typhoid vaccine. Antigenic composition of such vaccine based on two highly-purified safe polysaccharides: Vi-capsular antigen and LPS which provides protection against wide-spectra 
typhoid fever strains including $\mathrm{Vi-negative} \mathrm{strain.}$ Immunopotentiator biodestructive carrier shall be used as delivery system. We consider low-toxic \& pyrogenic LPS simultaneously as antigen and as adjuvant for immunogenicity increase of whole vaccine construction. Optimal design, composition, safety profile evaluation of new vaccine are the subject of nearest investigation.

\section{References}

1. Tacket CO, Levine MM, Robbins JB. Persistence of antibody titres three years after vaccination with Vi polysaccharide vaccine against typhoid fever. Vaccine 1988; 6: 307-8.

2. Requirements for $\mathrm{Vi}$ polysaccharide typhoid vaccine (Requirements for Biological Substance No.48). World Health Organization. WHO Technical Report Series. No 840 1994; 14-32. 